AGRICULTURE AND BIOLOGY JOURNAL OF NORTH AMERICA

ISSN Print: 2151-7517, ISSN Online: 2151-7525, doi:10.5251/abjna.2011.2.8.1182.1186

(C) 2011, ScienceHu $\beta$, http://www.scihub.org/ABJNA

\title{
Investigation the importance and trends of forest yield production considering economical and environmental objectives
}

\author{
Majid Lotfalian ${ }^{1}$ Kiomars Mohammadi Samani ${ }^{2}$ Samira Pirzad Far ${ }^{3}$ \\ 1. Associate professor, Department of Forestry, Faculty of Natural Resources, Sari \\ Agricultural Sciences and Natural Resources University, Sari, Iran \\ ${ }^{2}$ Assistant Professor, Department of Forestry, Faculty of Natural Resources, University of \\ Kurdistan \\ ${ }^{3}$ Graduate Student of Forestry, Department of Forestry, Faculty of Natural Resources, Sari \\ Agricultural Sciences and Natural Resources University, Sari, Iran.
}

\begin{abstract}
The transformation of forest products from forest-logged products (lumber etc.) into logs will reduce the pressure on the northern forests of Iran in addition to improving the forest product's values. In order to investigate the altering trend of the woody products yielded from the northern forests of Iran, the statistics concerning the production rate of each of the products (i.e. logs, lumber, bolts, traverse, pole wood and charcoal) were prepared. To give a comparison on the product's variation trend, the data were converted into the percent of total annual wood production. The results showed that logs, bolts, and fuel woods have had an increasing trend while lumber, charcoal, and traverses followed a declining way. Meanwhile, pole wood's trend showed to be constant during the time. The increase in logs and fuel wood along with the decrease in lumber and traverse can be mainly attributed to the reasons including the recent improvement of forest road construction over the region, the application of powerful forest harvest machine, the alteration in wood consumption pattern in northern country, the changes in the general wood application, increasing the use of oil fuels, enrichment of the technological capabilities, and higher values of logs.
\end{abstract}

Keywords: Forest products; logs; environmental damages; industrial/traditional logging; wood industry

\section{INTRODUCTION}

When the timber products of forest change from bucking size to log, in spite of increasing value and decreasing environmental damage the pressure on forest also decrease. In order to evaluate the conversion status of products in commercial forest of Iran, the data related to production rate of log, lumber, bolts, traverse, pole wood and charcoal was provided. Hyrcanian forests with an area of about 1.9 million hectare are located in north of Iran, in southern coast of Caspian Sea. It is exclusive site for some valuable and unique species like Gleditsia caspica Desf., Parrotia persica C.A. Meyer., and Pterocarya fraxinifolia (Lam.) Spach. IR-Iran government is the owner of almost all forests in Iran. Only northern forests of Iran or Hyrcanian forest zone are commercial and industrial.

Forest functions, wood and non-timber forest products are valued more and more, refined, exploited commercially, protected, or managed sustainable. This information can only be provided by integrating the known system details and up scaling to the stand or landscape level, where such management decisions are made (WILLIAMSON, NEILSON 2000; PRETZSCH 2009). A principal concern is with measurement of the amount of wood trees contain in their stems and the sizes of the logs that can be cut from them. It is this wood that is converted into timber products (lumber as it is called in America), for building and many other purposes, or that is to be used for paper-making (JOHNS et al. 2004; WEST 2009).

In Republic of Korea the total value of forest products in 2000 was about US\$1,600 million, represent $0.2 \%$ of the national Gross domestic product. The economic value of timber production did not exceed US $\$ 90.8$ million, resulting in most of the economic value coming from mushrooms, nuts, and other nontimber products (STANTURF, MADSEN 2005).Nowadays, Commercialization of non-timber forest products has been widely promoted as an 
approach to rural development in forest areas (JOHNS et al. 1996; MARSHALL et al. 2006).

The objectives of this study were to investigate the importance of the forest product changes in relation to economic and environmental purposes.

\section{MATERIALS AND METHODS}

Study area: Iran is low forest cover country (LFCC) with the forest cover of $7.4 \%$. Hyrcanian Forest comprises $15 \%$ of the total Iranian forest and $1.1 \%$ of the country's area. The commercial forests of Iran are located in longitude $48^{\circ} 30^{\prime}$ to $54^{\circ} 30^{\prime}$ and latitude $35^{\circ} 46^{\prime}$ to $36^{\circ} 58^{\prime}$. This moderate forest is a green belt stretching over the northern slopes of Alborz mountain ranges and covers the southern coasts of the Caspian Sea. It has a total area of 1.9 million ha, which $60 \%$ of its stock growth is passed from logging age (FOOD and AGRICULTURE ORGANIZATION 1999). Hyrcanian or northern forests of Iran stretch up to an altitude of $2300 \mathrm{~m}$ above sea level and encompass different forest types thanks to their 80 trees and shrub species. The forests are dominated by Fagus orientalis Lipsky, Quercus castanifolia C.A.M., Alnus glutinosa Gaertn and it is exclusive site for some valuable species like Populus caspica Bornm, Gleditsia caspica Desf, Parrotia persica Mever, Pterocaria fraxinifolia (Lam.) Spach, Acer laetum and Carpinus betulus $L$. It is exclusive site for some valuable and unique species like Gleditsia caspica Desf., Parrotia persica C.A. Meyer., and Pterocarya fraxinifolia (Lam.) Spach. These forests are seeding crop, uneven aged and combined by different broadleaves species and varying in type, age, diameter and height. In Iran, shelterwood cutting in northern hardwood forest has given rise to public concern in recent years, mainly because of its negative impacts on silvicultural properties, biological and aesthetical values (Fig. 1).

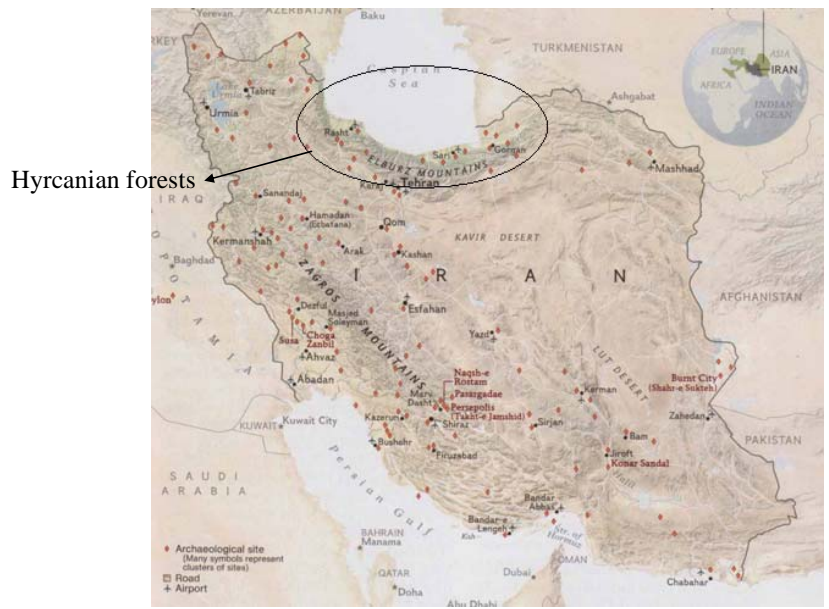

Fig 1. The position of study area

Data collection: In order to investigate the changing process of forest products, the volume data related to different types of utilization from timber products of Hyrcanian forests in four regions Guilan, Noshahr, Sari and Gorgan were collected (work report of forests, rangelands and watershed conservation organization from 1976 to 2005). Then the statistics concerning the production rate of each of the products (i.e. logs, lumber, bolts, traverse, pole, wood and charcoal) were prepared in cubic meter. The coal is sold in tone and 1 tone charcoal is produced from each $7 \mathrm{~m}^{3}$ wood. To give a comparison on the product's variation trend, the data were converted into the percent of total annual wood production.

\section{RESULTS AND DISCUSSION}

The results showed that in Guilan the production rate of logs, bolts and wood increased from 1976 to 2005, while the production rate of lumber, traverse and charcoal decreased (Fig. 2). In Noshahr, the production rate of logs, traverse, bolts and wood increased from 1976 to 2005, while production rate of lumber and charcoal decreased. The production rate of pole did not change during these years (Fig. 3). In Sari, the production rate of log, bolt and wood increased from 1976 to 2005, while the production rate of lumber, traverse and charcoal decreased. The production rate of pole was steady (Fig. 4). In Gorgan, the production rate of logs, traverse, bolts and wood increased and pole, lumber and charcoal decreased (Fig. 5). 


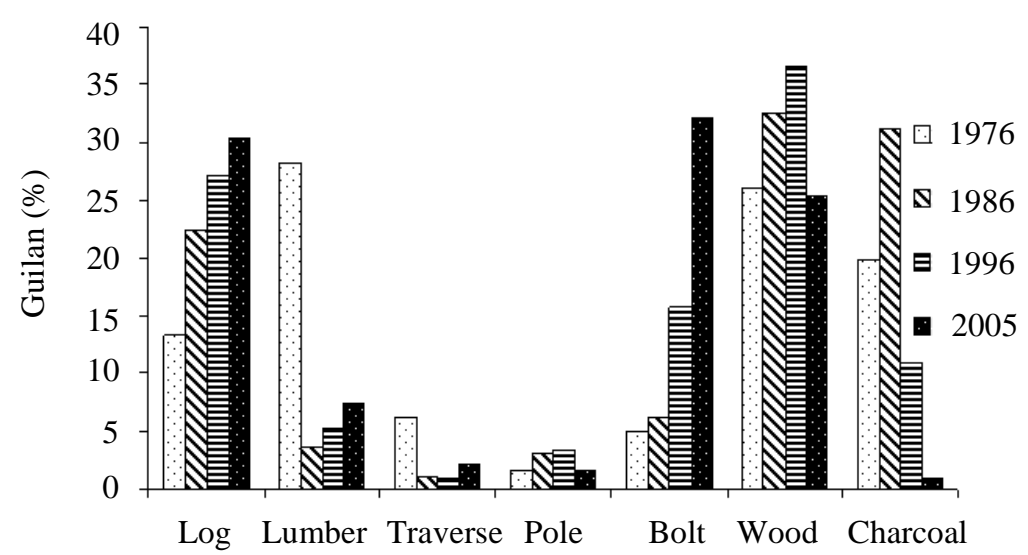

Fig 2. Changing process of forest products in Guilan province from 1976 to 2005

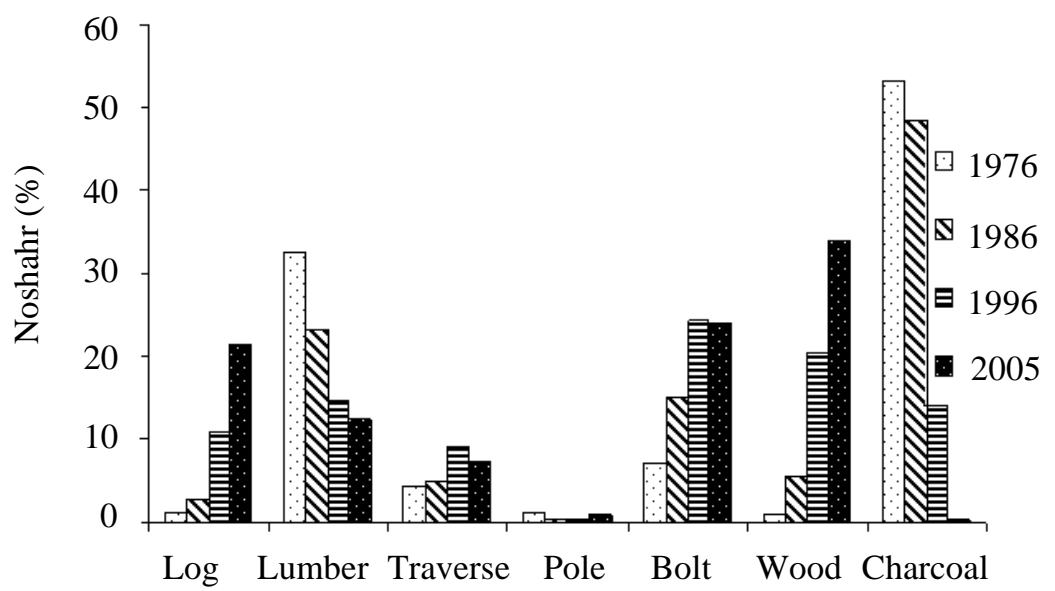

Fig 3. Changing process of forest products in Noshahr from 1976 to 2005

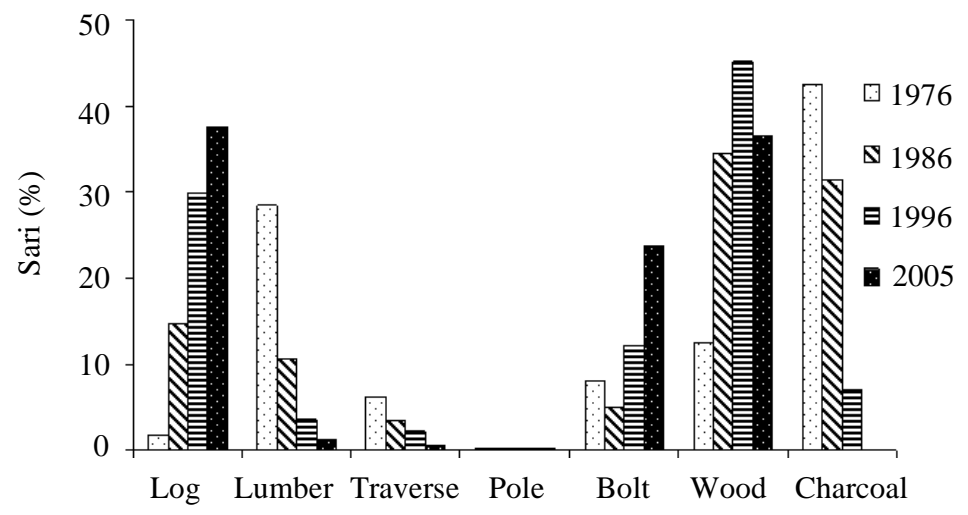

Fig 4. Changing process of forest products in Sari from 1976 to 2005 


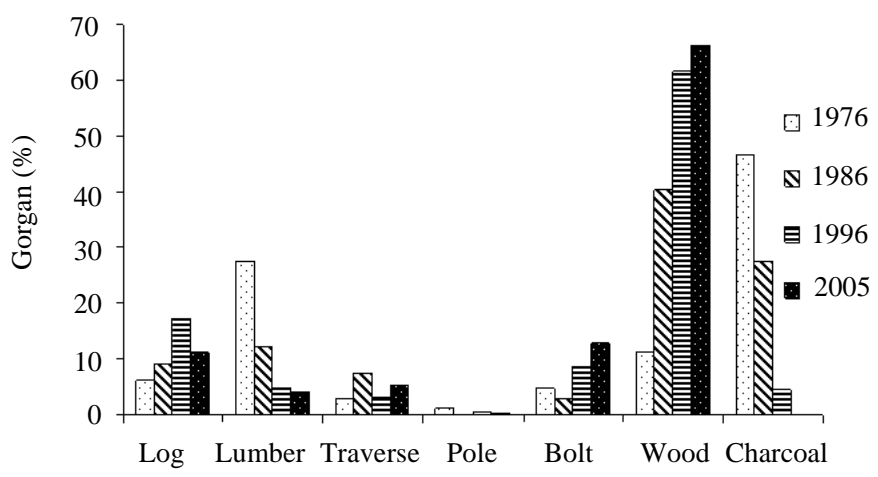

Fig 5. Changing process of forest products in Gorgan from 1976 to 2005

Logs, bolts, and fuel woods have had an increasing trend while lumber, charcoal, and traverses followed a declining way (ADRIAN et al. 2005). Meanwhile, pole wood's trend showed to be constant during the time (Fig. 6). The increase in logs and fuel wood along with the decrease in lumber and traverse can be mainly attributed to the reasons including the recent improvement of forest road construction over the region, the application of powerful forest harvest machines (e.g. skidders etc.), the alteration in wood consumption pattern in northern country (chiefly following the installation of major wood and paper industries), the changes in the general wood application, increasing the use of oil fuels (as an alternative for some products such as fuel wood and charcoals), enrichment of the technological capabilities, and higher values of logs (compared to other wood products) (DUDLEY et al. 1995; MAGIN 2001; DANIEL et al. 2005). Consequently, the damages associated with forest harvest/road construction machines and the logging wastages can be significantly reduced by an appropriate forest resource planning aided by precise environmental considerations (Table 1).

Table 1. Reports of forest products in years 1976, 1986, 1996 and 2005 based on forests, rangelands and watershed organization database

\begin{tabular}{|l|c|c|c|c|c|c|c|c|}
\hline $\begin{array}{l}\text { Product } \\
\text { Area }\end{array}$ & $\begin{array}{c}\text { Logs } \\
\left(\mathbf{m}^{\mathbf{3}}\right)\end{array}$ & $\begin{array}{c}\text { Lumber } \\
\left(\mathbf{m}^{\mathbf{3}} \mathbf{)}\right.\end{array}$ & $\begin{array}{c}\text { Traverses } \\
\left(\mathbf{m}^{\mathbf{3}} \mathbf{)}\right.\end{array}$ & $\begin{array}{c}\text { Pole } \\
\left(\mathbf{m}^{\mathbf{3}} \mathbf{)}\right.\end{array}$ & $\begin{array}{c}\text { Bolts } \\
\left(\mathbf{m}^{\mathbf{3}} \mathbf{)}\right.\end{array}$ & $\begin{array}{c}\text { Wood } \\
\left(\mathbf{m}^{\mathbf{3}} \mathbf{)}\right.\end{array}$ & $\begin{array}{c}\text { Coal } \\
\left(\mathbf{m}^{\mathbf{3}}\right)\end{array}$ & $\begin{array}{c}\text { Total } \\
\left(\mathbf{m}^{3} \mathbf{)}\right.\end{array}$ \\
\hline Year & 1976 & 1976 & 1976 & 1976 & 1976 & 1976 & 1976 & 1976 \\
\hline Guilan & 27609 & 58884 & 12992 & 3090 & 10278 & 54449 & 41355 & 208657 \\
\hline Noshahr & 1249 & 36645 & 4910 & 1196 & 7955 & 985 & 59831 & 112771 \\
\hline Sari & 5528 & 88186 & 18765 & 749 & 24852 & 38801 & 131847 & 308727 \\
\hline Gorgan & 7772 & 35075 & 3463 & 1541 & 6085 & 14111 & 59273 & 127320 \\
\hline Total & 42158 & 21870 & 40130 & 6576 & 49170 & 10834 & 292306 & 757476 \\
\hline Year & 1986 & 1986 & 1986 & 1986 & 1986 & 1986 & 1986 & 1986 \\
\hline Guilan & 58840 & 9106 & 2923 & 7990 & 16207 & 85103 & 81582 & 261351 \\
\hline Noshahr & 6149 & 51703 & 10571 & 572 & 33575 & 12400 & 107520 & 222494 \\
\hline Sari & 83407 & 60331 & 18992 & 1644 & 28525 & 195715 & 177990 & 566604 \\
\hline Gorgan & 19003 & 25425 & 15862 & 131 & 5838 & 84377 & 57432 & 208068 \\
\hline Total & 166999 & 146565 & 48348 & 10337 & 84149 & 377596 & 424524 & 1258518 \\
\hline Year & 1996 & 1996 & 1996 & 1996 & 1996 & 1996 & 1996 & 1996 \\
\hline Guilan & 116561 & 22823 & 3680 & 14698 & 67767 & 157306 & 47130 & 429965 \\
\hline Noshahr & 27982 & 38237 & 24287 & 394 & 63633 & 53625 & 54360 & 262518 \\
\hline Sari & 180153 & 21303 & 13361 & 790 & 72750 & 272725 & 42144 & 603226 \\
\hline Gorgan & 46412 & 12448 & 8037 & 1130 & 23071 & 165687 & 12102 & 268887 \\
\hline Total & 371108 & 94811 & 49365 & 17012 & 227221 & 349343 & 155736 & 1564596 \\
\hline Year & 2005 & 2005 & 2005 & 2005 & 2005 & 2005 & 2005 & 2005 \\
\hline Guilan & 53559 & 13087 & 3704 & 2812 & 56445 & 44433 & 1624 & 183784 \\
\hline Noshahr & 29943 & 17538 & 10222 & 1303 & 34092 & 47892 & 228 & 142358 \\
\hline Sari & 155467 & 5089 & 2879 & 623 & 98458 & 151359 & 0 & 413875 \\
\hline Gorgan & 10678 & 3908 & 5141 & 260 & 12414 & 63863 & 0 & 96264 \\
\hline Total & 249647 & 39622 & 21496 & 4998 & 201409 & 307547 & 1852 & 836281 \\
\hline
\end{tabular}




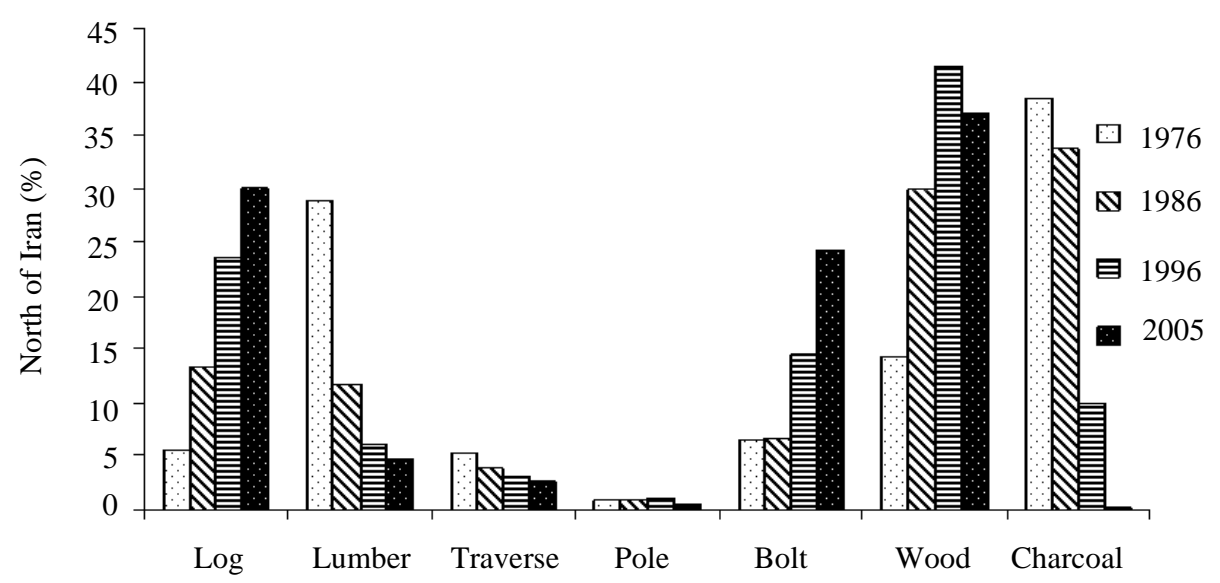

Fig 6. Changing process of forest products for mentioned four regions in northern forests of Iran from 1976 to 2005

CONCLUSIONS: In summary it was concluded that in northern forests of Iran the production rate of logs, bolts and wood increased from 1976 to 2005, while the production rate of lumber, traverse and charcoal decreased. The increase in logs and fuel wood along with the decrease in lumber and traverse can be mainly attributed to the reasons including the recent improvement of forest road construction over the region, the application of powerful forest harvest machine, the alteration in wood consumption pattern in northern country, the changes in the general wood application, increasing the use of oil fuels, enrichment of the technological capabilities, and higher values of logs.

\section{REFERENCES}

Adrian, A., Thomas, A., Richard, E., Miller, H., Anderson, W and Flaming, L (2005). Ground-Based Forest harvesting Effects on Soil Physical Properties and Douglas-fir Growth. Soil Sci. Soc. Am. J. 69: 18221832.

Daniel, A., "chli, K and Brang, P (2005). Simulating effects of forest management on selected public forest goods and services: A case study. Forest Ecology and Management 209 .57-68.

Dudley, N., Jeanrenaud, J.P and Sullivan, F (1995). Bad Harvest? The timber trade and the degradation of the world's forests. Earthscan, London, UK.

Food and Agriculture Organisation .(1999). State of the world's forests 1999. Food and Agricultural Organisation, Rome.
Williamson, J.R and Neilson, W.A (2000). The Influence of Forest Site on Rate and Extent of Soil Compaction and Profile Disturbance of Skid Trails During Ground-Based Harvesting. Can. J. For. Res. 30: 1196-1205.

Johns, J.S., Barreto, P and Uhl, C (1996). Logging damage during planned and unplanned logging operations in the eastern Amazon. Forest Ecol. Manage. 89, 59-77

Johansson, A (1999). Costs continue to fall. SkogForsk. Results No. 3,. 4pp.

Keller, M. Palace, M. Asner, G.P. Pereira, R. Silva, J.N.M. (2004). Coarse woody debris in undisturbed and logged forests in the eastern Brazilian Amazon. Global Change Biol. 10, 784-795.

Magin, G (2001). An introduction to wood waste in the UK. Fauna \& Flora International, Cambridge, UK; 40 pages.

Marshall, E., Schreckenberg, K and Newton, A.C (2006). Commercialization of Non-timber Forest Products: Factors Influencing Success. Lessons Learned from Mexico and Bolivia and Policy Implications for Decision-makers. UNEP World Conservation Monitoring Centre, Cambridge, UK.

Pretzsch, H (2009). Forest Dynamics, Growth and Yield. Springer publication, ISBN: 978-3-540-88306-7, 660 p.

Stanturf, J.A and Madsen, P (2005). Restoration of Boreal and Temperate. published in the Taylor \& Francis eLibrarym, ISBN 0-203-59157-7, 675 p.

West, P.W (2009). Tree and Forest Measurement. Springer publications, ISBN: 978-3-540-95965-6, 190 p. 